\title{
THE COST OF INNOVATION AND DECREASING BOOK EQUITY OF U.S. FIRMS
}

\section{HAOWEN LUO1}

1. Purdue University Fort Wayne, Finance, USA

* Corresponding Author: Haowen Luo, Department of Economics and Finance, Purdue University Fort Wayne, Finance, 2101 Coliseum Blvd East Fort Wayne, IN 46805

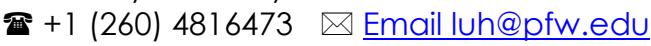

\begin{abstract}
This study documents that book equity of U.S. firms has decreased dramatically over time and such decrease is systematic across various industries and firm size. Our analysis shows that intangible capital investment explains a significant portion of the decrease in book equity even after controlling for the concurrent effect of leverage and profitability on book equity, and the effect of intangible capital investment on book equity increased in recent years. Further analysis shows that intangible capital contributes to a decrease in book equity mostly through the channel of changing firm characteristics rather than changing sensitivity over time. Our findings suggest that investors must incorporate the effect of intangible capital investment into their valuation analysis, as indexes or investment strategies relying on indicators constructed by book equity may be biased and misleading.
\end{abstract}

Keywords: Book Equity, Intangible Assets, Innovation

JEL: G30, G31

\section{Introduction}

Many of America's largest companies currently have a book value that is small relative to their market value. Some firms' 1 , including AutoZone and McDonald's, even report a negative book value. Such empirical regularity has been noticed by some recent studies. For example, Jan and Ou (2012), Brown et al. (2008) and Luo et al. (2019) have documented the systematic increase in the frequency of firms with negative book equities across various industries and sizes. Although negative book equity firms are extreme examples, the rapid increase in such firms may indicate a shift in or reshaping of entire distributions of book equity of U.S. firms, a topic that has not been discussed in prior literature. Our study is thus motivated to fill this gap by studying aggregate trends in the book equity (B.E.) of U.S. firms over the past four decades. Specifically, our paper intends to address the following general questions: Has the book equity of U.S. firms systematically decreased over time? If so, what are the possible driving forces?

1 Other noticeable long-time negative book equity firms include Revlon and DirecTV before it merged with AT\&T 
In our analysis, we first document that the book equity (B.E.) of U.S. firms has been consistently decreasing since the 1960s. The average book equity of U.S unregulated firms decreased from $61 \%$ of total asset in 1960 to $43 \%$ in 2017 . Such a decrease is prevalent among firms from different industries and with different size in a consistent pattern. There are a few potential reasons that can be implied from previous literature for such a trend. First of all, it is well documented in finance and accounting literature 2 that the frequency of reported losses has increased significantly over recent decades. The systematic decrease in earnings on income statement may lead to a decrease in book equity on the balance sheet through decreased retained earnings. Secondly, as pointed out by Graham et al. (2015), unregulated firms dramatically increased their debt financing, and aggregate leverage of U.S. firms more than tripled over the past century. As corporate debt financing squeezes the room for equity financing in firms' capital structure, it is not surprising to observe the decreasing trend of book equity along with the increasing trend of leverage.

In this paper, we argue that another possible reason for decreasing B.E. is the increased impact of intangible capital investment. Specifically, we contend that, although profitability and leverage are important determinants of firms' book equity, firm's investment on intangible capital also play a critical role in regulating its book equity even after controlling for the effect of profitability and leverage. As a gauge of a firm's net asset, book equity should proxy for the abandonment value of firms because the bulk of book value is made up by fixed capital assets, such as factories, machines, land and office buildings, as well as current assets. Such proxy works fine in the non-digital age when firms' assets are mostly tangibles. However, as we are moving toward a knowledge-based economy, the complexity of valuing a firm's assets has increased dramatically, and problem raises with the old book equity measurement due to what it leaves out: investment in knowledge and intangibles such as human capital, research and development, and relationships with customers and suppliers. By their nature, these intangible assets are difficult to value and are not directly reflected by book equity. Nonetheless, the heavy research, marketing, and networking activities cause firms to incur expenditure which will reduce the tangible assets on the balance sheet while creating an off-balance sheet intangible asset. The more intangible assets that a firm acquires or develops, the faster book value of equity should decrease. As a result, we should obtain a negative relationship between intangible capital investment and book equity.

To test this conjecture, we use a newly developed proxy for intangible capital by Peter and Taylor (2017) and investigate how it related with book equity using a sample of nonregulated firms over past four decades. Our main findings confirm that a significant portion of the secular decrease in B.E. can be explained by an increase in intangible capital under various model specifications. In addition, we find that the explanatory power of intangible capital has been increasing over time, and there is a fundamental shift in the sensitivity of B.E. to intangible capital investment. In further analysis, we isolate the effect of changing firm characteristics from that of changing sensitivity of explanatory variables and show that both are important to explain the variation of B.E. in our sample.

Our findings have several empirical implications. First, BE is widely used by investors to differentiate value stocks from growth stocks in the form of price-to-book ratios. Although many previous studies have shown that buy-and-hold value stocks represent

2 See Collins et al. (1999), Burgstahler and Dichev (1997) and Barth et al. (1998) 
a winning strategy, recent findings suggest that value stocks have lagged behind the general market and are far behind growth stocks. Our finding suggests that such empirical observations may be due to measurement errors, as the B.E. of U.S. firms has systematically changed over time. Second, our intangible-capital-based explanation suggests that the increasing discrepancy between market value and book value is due to the intangible nature of investment in knowledge and human capital. As the industrial age gives way to the digital age, intangible capital investment matters increasingly as the crucial driver of corporate innovation and its long-term viability. As a result, accounting rules must be modified so that book value can reflect past intangible capital investment activities for more useful comparisons across stocks.

We organize the remainder of the paper as follows. Section 2 provides an overview of the long-term trend of book equity. In section 3, we develop and test main hypotheses using various model specifications-section 4 focus on identifying and quantifying driving forces of decreasing book equity. Then we performed a robustness check in Section 5. Conclusions are in Section 6.

\section{An Overview of Long-Term Trend of Book Equity}

We start with an overview of the long-term trend of book equity for unregulated U.S firms. In this analysis, our sample comprises public-traded firms, excluding financial (SIC codes 6000-6999), utility (SIC codes 4900-4999), firms classified as public service, international affairs, or non-operating establishments ( SIC codes greater than 9000) ${ }^{3}$ and non-US firms (FIC = USA), from 1960 to 2017. Following previous literature (Fama and French, 2008), the book equity is defined as the sum of shareholders' book equity and balance sheet deferred taxes and investment tax credit, subtracting the book value of preferred stock. We standardize B.E. using the total asset.

Figure 1 shows the B.E. has decreased significantly between 1960 and 2017. Average (Median) BE dropped by nearly 26\% (23\%), from 0.61 (0.62) in 1960 to $0.45(0.48)$ in 2017. To test whether such a decrease is industry-specific, in Figure 2, we evaluate the trend across different industry classifications (defined as in Fama-French 12 industry codes). The results suggest that the secular decrease in book equity is persistent for firms from all industries and that such trend is more pronounced for firms within industries that have gone through technological transformation or known for R\&D intensive, such as the manufacturing (FF12=3), chemical (FF12=5), pharmaceutical (FF12=10) and Information Technology (FF12=7) industries. In particular, for the information technology industry, the B.E. is consistently lower than in other industries and continue decreasing. The findings from Figure 2 suggest that one possible explanatory factor for decreasing B.E. over time is intangible-driven innovation: in an increasingly knowledge-based economy, typical firms switch from investing in tangible assets to intangible assets. Under current accounting rules, however, intangible investments are expensed rather than capitalized for most firms. As a result, balance sheets fail to reflect the true value of B.E., especially for firms heavily invested in unrecorded intangible capital.

It is also possible that observed long term trend of B.E. is driven by firms with a particular size. In figure 3, we further examine the trend of B.E. by firm size quintiles. Firm size is

3 This sample restriction is required by Peter and Taylor (2017) in order to use their intangible capital investment measurement. 
measured by sales standardized by total assets. Figure 3 illustrates the time series trend of average B.E. sorted by firm size quintiles during our sample period. Similar to Figure 1 and Figure 2, we observe that B.E. decreased over time in all firm size quintiles. In particular, the decrease in B.E. is more pronounced for firms fall into top and bottom size quintiles. Also, the B.E. for the largest firms in our sample (quintiles=5) is systematically lower than that of relatively smaller firms.

Figure 1: The secular trend in book equity overtime

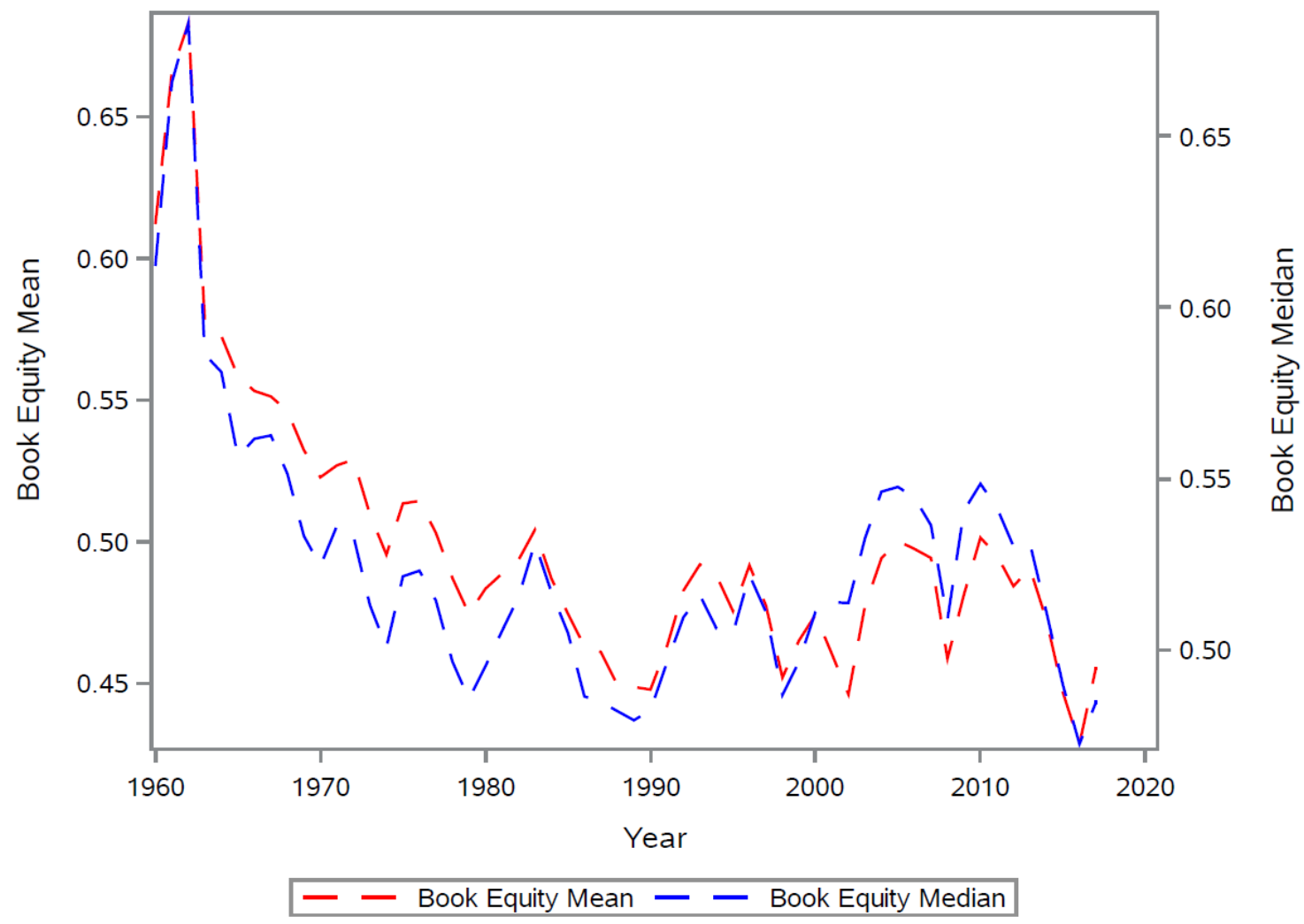

Figure 2: The secular trend in book equity by industry
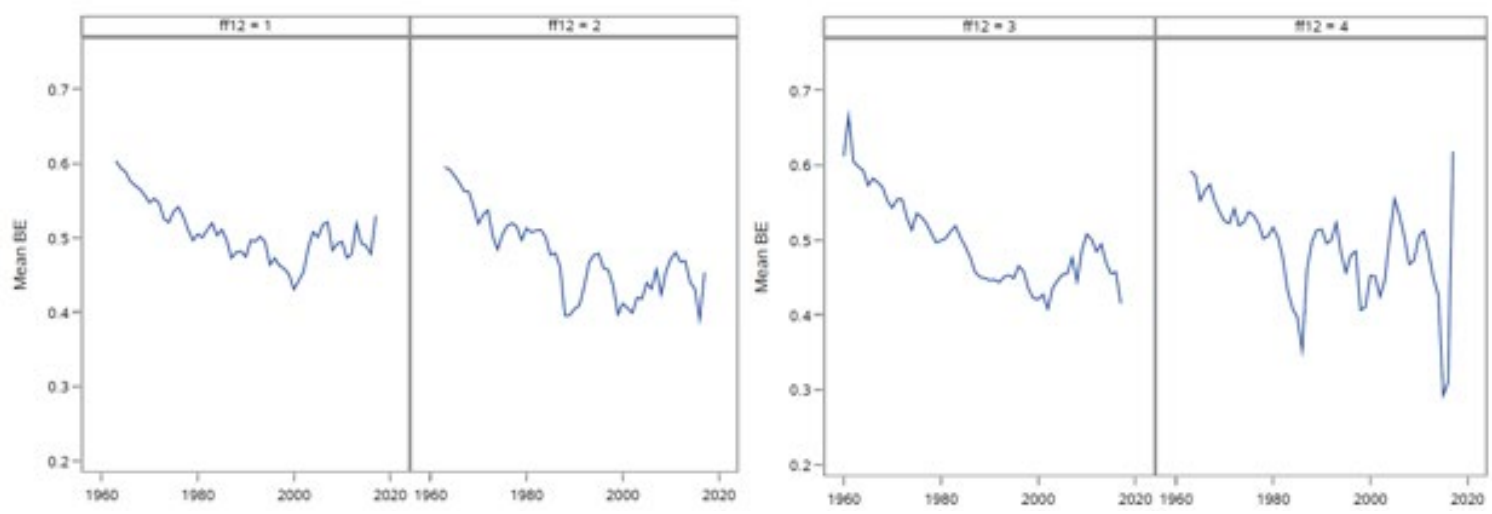

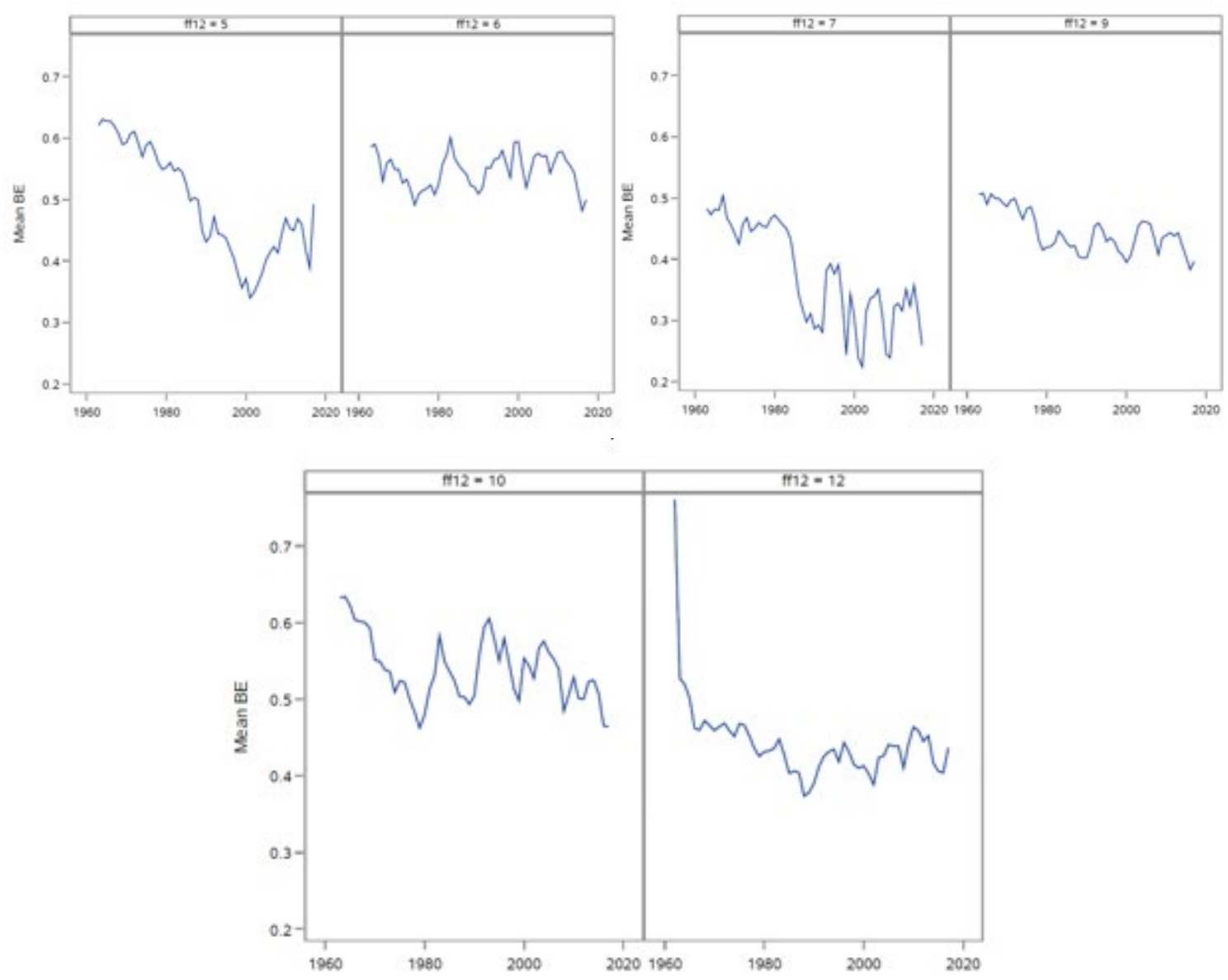

Figure 3: The secular trend in book equity by size quintiles

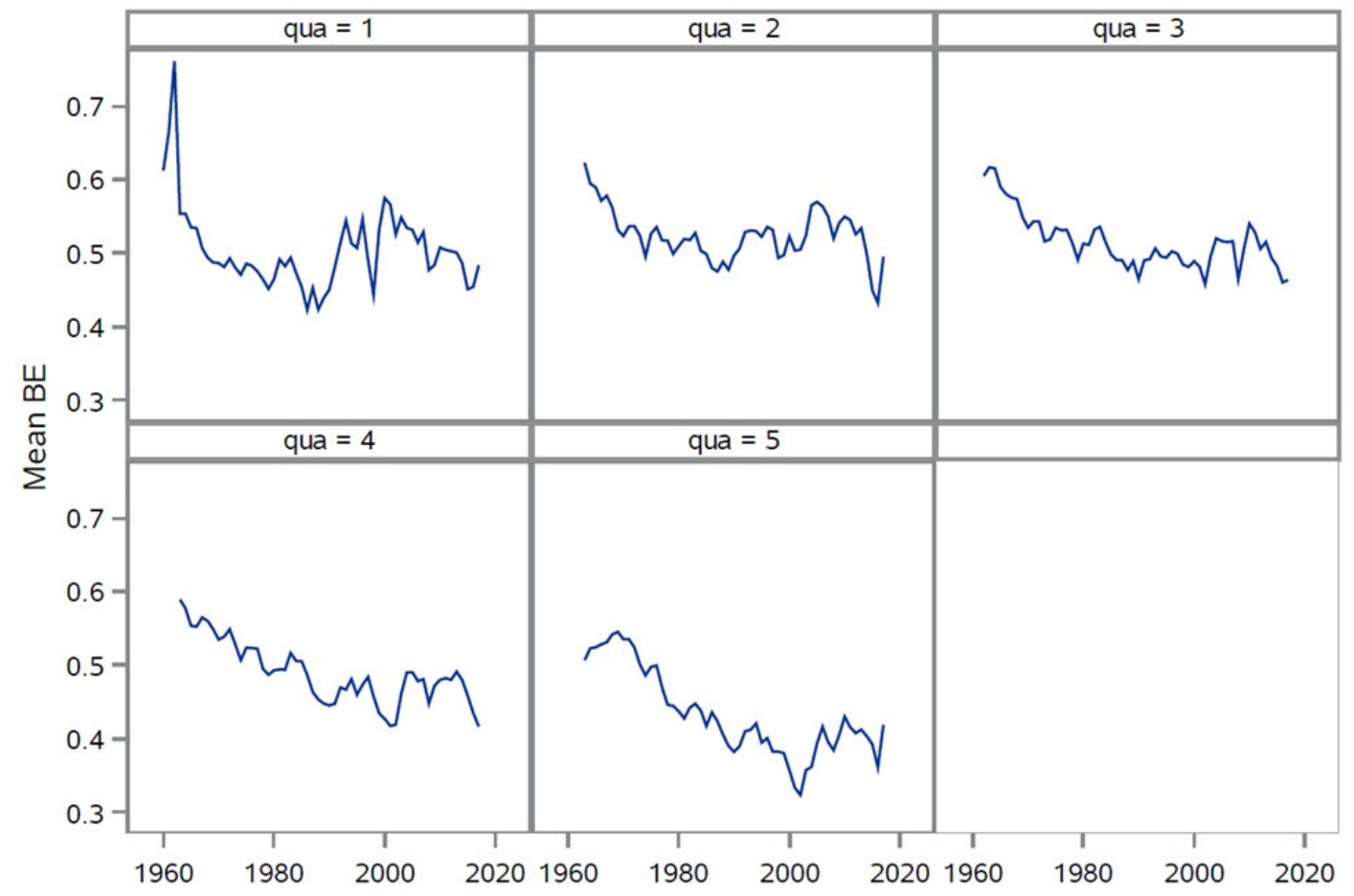




\section{How Intangible Investments Affect Book Equity}

\subsection{Hypothesis development}

The decreasing trend of B.E., as documented in the previous section, is interesting. Such observation coincides with two previously documented stylized empirical regularities with respect to firm characteristics. First, several studies have documented a downward shift in average earnings among firms in recent decades (Fama and French (1995), Opler and Titman (1994)). As the direct consequence, retained earnings are decreased over time and, assuming other factors unchanged, B.E. of average firms is affected negatively. Second, debt usage of unregulated firms has dramatically increased over time (Graham et al. (2015) and Philippon (2009)). This shift was largely driven by a systemic change in financial leverage, and firms of all sizes and all industries are affected. DeAngelo and Roll (2014) also find that over 1950 to 2008, leverage increased more frequently than it decreased among firms, which is the evidence of wholesale abandonment of conservative leverage. If the majority of firms are prone to more debt financing over time, then we should observe a gradually contracting equity portion on the balance sheet along with an expanding debt section.

Although both profitability and leverage may explain some variation in book equity observed in our sample, they are not the only factors. In this paper, we argue that investment in intangible capital also plays an important role in explaining long term variation in book equity. Many industries nowadays are transferring from tangible-based ones to information- and technology-based ones. Accordingly, the value of a firm within these industries lies as much in its intangible investments as in tangible assets. However, under the current accounting rule, not every dollar of intangible investments can be ascribed to a well-defined asset and reflected by net asset as measured by book equity. In other words, the book value of equity is not adjusted to reflect past intangible investment which is increasing across firms from many different industries. As a result, the decreasing book equity is the mere consequence of increasing intangible capital investment due to systematic industrial transformation. Therefore, based on previous discussion and observations, it led us to make the following broad prediction that we test in the paper:

Hypothesis 1: Intangible capital investment is negatively related to book equity.

\subsection{Methods and data}

The main variable of interest, intangible capital investment, is based on a newly developed proxy for intangible capital by Peters and Taylor $(2017)^{4}$. This measurement, denoted as $K^{\text {int }}$ in their studies, is intended to capture the replacement cost of firms' intangible capital both purchased externally, such as goodwill and intangibles reported on the balance sheet and created internally within the firm, such as R\&D (which is referred to as knowledge capital) and SG\&A (which is referred to as organization capital). We standardize intangible capital investment at firm level as calculated by Peters and Taylor (2017) using total assets for each firm. One limitation of using this measurement is that we can only use observations starting in 1975 in our regression analysis because the Federal Accounting Standards Board (FASB) only require firms to report R\&D after 1974.

\footnotetext{
${ }^{4}$ We appreciate authors for sharing the data through WRDS
} 
To control for other firm characteristics that are related to book equity, we also include a set of control variables in our empirical analysis. These variables include the following: profitability, defined as operating income before depreciation over book assets; firm size, defined as the natural log of a firm's total assets; share repurchase, defined as the ratio of share repurchases to total assets; industry sales volatility, calculated as the standard deviation of sales over total assets for 5 years' rolling window for each industry (3 digit SIC code); tangibility, defined as property, plant and equipment to book assets; leverage, calculated as total debt over total assets; capital expenditure, measured by capital expenditure divided by total asset, and dividend dummy, which takes the value of 1 if the firm pays a dividend in that year and 0 otherwise. Our final sample consists of 129,444 firm-year observations between 1975 and 2017. We winsorized all regression variables at the $1 \%$ level to remove outliers.

We test hypothesis 1 using the empirical model generally specified below:

$$
B E_{i, t}=\alpha+\beta_{0} \text { Intangible Capital }{ }_{i, t-1}+\beta_{1} X_{i, t-1}+\varepsilon_{i, t}+\gamma_{j}+\delta_{t}
$$

where B.E. is the book equity-to-asset ratio for firm $\mathrm{i}$ in year $\mathrm{t}$, Intangible capital is the standardized replacement cost of firms' intangible capital calculated by Peters and Taylor (2017), and $X$ is a vector of control variables as introduced previously. All independent variables are lagged 1 year to mitigate the reverse causality problem. Equation 1 also include industry $\left(\gamma_{j}\right)$ and year fixed $\operatorname{effect}^{5}\left(\delta_{t}\right)$.

\subsection{Summary Statistics}

Panel A of Table 1 displays descriptive statistics for all the variables for the full sample. The mean (median) book equity-to-asset ratio is 0.48 (0.51). The mean (median) intangible capital is $0.56(0.45)$, suggesting that off-balance-sheet intangible assets are accounting for a large portion of the total asset on average. The average leverage, industry sales volatility, capital expenditure and profitability are $0.25,0.06,0.07$ and 0.10 , respectively. Panel $\mathrm{B}$ of Table 1 reports pairwise correlation coefficients. It appears that intangible capital is negatively related to book equity, and the correlation coefficient is significant at the $1 \%$ level. Variables that are positively related with book equity are share repurchase, dividend dummy, and profitability; Variables that are negatively related with book equity are leverage, size, industry sales volatility, tangibility, and capital expenditure. All correlation coefficients are significant at the $1 \%$ level.

To visualize how intangible capital investment and book equity comoves during our sample period, in figure 4 , we plot the time series trend of both variables calculated as the average per year. The figure demonstrates that, as book equity decreased over the past 4 decades from over $51 \%$ of total assets in 1975 to less than $40 \%$ of total assets in 2016, average intangible capital has steadily increased from less than $44 \%$ of total assets to over $60 \%$ of total assets. The findings from Figure 4 suggest that one possible explanatory factor for decreasing book equity over time is an investment in innovation and intangible assets. In an increasingly knowledge-based economy, typical firms switch from investing in tangible assets to intangible assets. Under current accounting rules, however, intangible investments are expensed rather than capitalized for most firms. As a result, balance sheets fail to reflect the true value of net asset measured by book equity, especially for firms heavily invested in unrecorded intangible capital.

\footnotetext{
5 The use of pooled OLS with a single intercept is rejected by Breusch and Pagan (1980) LaGrange multiplier test. Hausman (1978) test suggest that fixed effects are the preferred specification for these data.
} 


\section{Table 1: $\quad$ Summary Statistics}

This table displays descriptive statistics of all financial variables over the sample period 1975-2017 in Panel A and Pearson correlation coefficient in Panel B. All variables are winsorized at the $1 \%$ level. Our sample consists of 129,444 firm-year observations, and we exclude financial (SIC codes 6000-6999), utility (SIC codes 49004999), firms classified as public service, international affairs, or non-operating establishments ( SIC codes greater than 9000) and non-US firms (FIC = USA). Book equity is defined as the sum of shareholders' book equity and balance sheet deferred taxes and investment tax credit, subtracting the book value of preferred stock, standardized by the total asset. Profitability, defined as operating income before depreciation over book assets; firm size, defined as the natural log of a firm's total assets; share repurchase, defined as the ratio of share repurchases to total assets; industry sales volatility, calculated as the standard deviation of sales over total assets for 5 years' rolling window for each industry (3 digit SIC code); tangibility, defined as property, plant and equipment to book assets; leverage, calculated as total debt over total assets; capital expenditure, measured by capital expenditure divided by total asset, and dividend dummy, which takes the value of 1 if the firm pays a dividend in that year and 0 otherwise.

\begin{tabular}{lccccccccc}
\hline \multicolumn{1}{c}{ Panel A: Full Sample (1975-2017) } & & & \\
\hline Variable & Mean & Median & $\begin{array}{c}\text { Std } \\
\text { Dev }\end{array}$ & Min & Q1 & Q3 & Max & N \\
\hline BE & 0.48 & 0.51 & 0.30 & -0.77 & 0.34 & 0.68 & 0.94 & 129,444 \\
Intangible Capital & 0.56 & 0.45 & 0.51 & 0.00 & 0.22 & 0.73 & 3.10 & 129,444 \\
\hline Leverage & 0.25 & 0.22 & 0.23 & 0.00 & 0.06 & 0.38 & 1.05 & 129,444 \\
Repurchase & 0.01 & 0.00 & 0.03 & 0.00 & 0.00 & 0.00 & 0.21 & 129,444 \\
Size & 5.08 & 4.88 & 1.98 & 1.28 & 3.60 & 6.41 & 10.17 & 129,444 \\
Dividend & 0.39 & 0.00 & 0.49 & 0.00 & 0.00 & 1.00 & 1.00 & 129,444 \\
Industrial Sales Volatility & 0.06 & 0.05 & 0.05 & 0.01 & 0.03 & 0.08 & 0.28 & 129,444 \\
Tangibility & 0.32 & 0.26 & 0.23 & 0.02 & 0.14 & 0.45 & 0.91 & 129,444 \\
\hline Profit & 0.10 & 0.12 & 0.17 & -0.73 & 0.06 & 0.18 & 0.41 & 129,444 \\
Capital Expenditure & 0.07 & 0.05 & 0.08 & 0.00 & 0.02 & 0.09 & 0.41 & 129,444 \\
\hline
\end{tabular}

\begin{tabular}{|c|c|c|c|c|c|c|c|c|c|}
\hline \multicolumn{10}{|c|}{ Panel B: Pearson Correlation Coefficients } \\
\hline Variable & ب் & 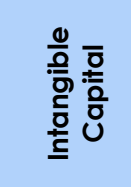 & 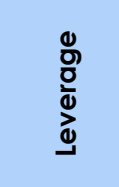 & 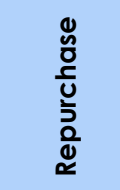 & $\stackrel{N}{n}$ & $\begin{array}{l}\frac{0}{0} \\
\frac{0}{0} \\
\frac{0}{2} \\
\frac{1}{0}\end{array}$ & 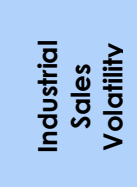 & $\begin{array}{l}\text { 를 } \\
\frac{0}{\sigma} \\
\text { 흐 }\end{array}$ & $\begin{array}{l}\text { ț } \\
\underline{0}\end{array}$ \\
\hline $\begin{array}{l}\text { Intangible } \\
\text { Capital }\end{array}$ & $-0.09 * * *$ & & & & & & & & \\
\hline Leverage & $-0.41^{* * *}$ & $-0.16^{* * *}$ & & & & & & & \\
\hline Repurchase & $0.03^{* * *}$ & $0.06^{* * *}$ & $-0.06^{* * *}$ & & & & & & \\
\hline Size & $-0.06^{* * *}$ & $-0.15^{* * *}$ & $0.3^{* * *}$ & $0.18^{* * *}$ & & & & & \\
\hline Dividend & $0.12^{* * *}$ & $-0.14^{* * *}$ & $0.13^{* * *}$ & $0.06^{* * *}$ & $0.33^{* * *}$ & & & & \\
\hline $\begin{array}{l}\text { Industrial } \\
\text { Sales Volatility }\end{array}$ & $-0.06^{* * *}$ & $-0.06^{* * *}$ & $0.06^{* * *}$ & $-0.02^{* * *}$ & $0.03^{* * *}$ & $0.06^{* * *}$ & & & \\
\hline Tangibility & $-0.11^{* * *}$ & $-0.4^{* * *}$ & $0.21^{* * *}$ & $-0.09^{* * *}$ & $0.01^{* * *}$ & $0.1^{* * *}$ & $0.06^{* * *}$ & & \\
\hline Profit & $0.21^{* * *}$ & $-0.34^{* * *}$ & $0.08^{* * *}$ & $0.15^{* * *}$ & $0.22^{* * *}$ & $0.31^{* * *}$ & $0.02^{* * *}$ & $0.09^{* * *}$ & \\
\hline Capital Expenditure & $-0.01^{* * *}$ & $-0.26^{* * *}$ & $0.06^{* * *}$ & $-0.05^{* * *}$ & $-0.09^{* * *}$ & $-0.01^{* * *}$ & $0.02^{* * *}$ & $0.57^{* * *}$ & $0.09^{* * *}$ \\
\hline
\end{tabular}

$*, * *$, and ${ }^{* * *}$ indicate statistical significance at the $10 \%, 5 \%$, and $1 \%$ level, respectively. 
Figure 4: Book equity V.S. intangible capital over Time

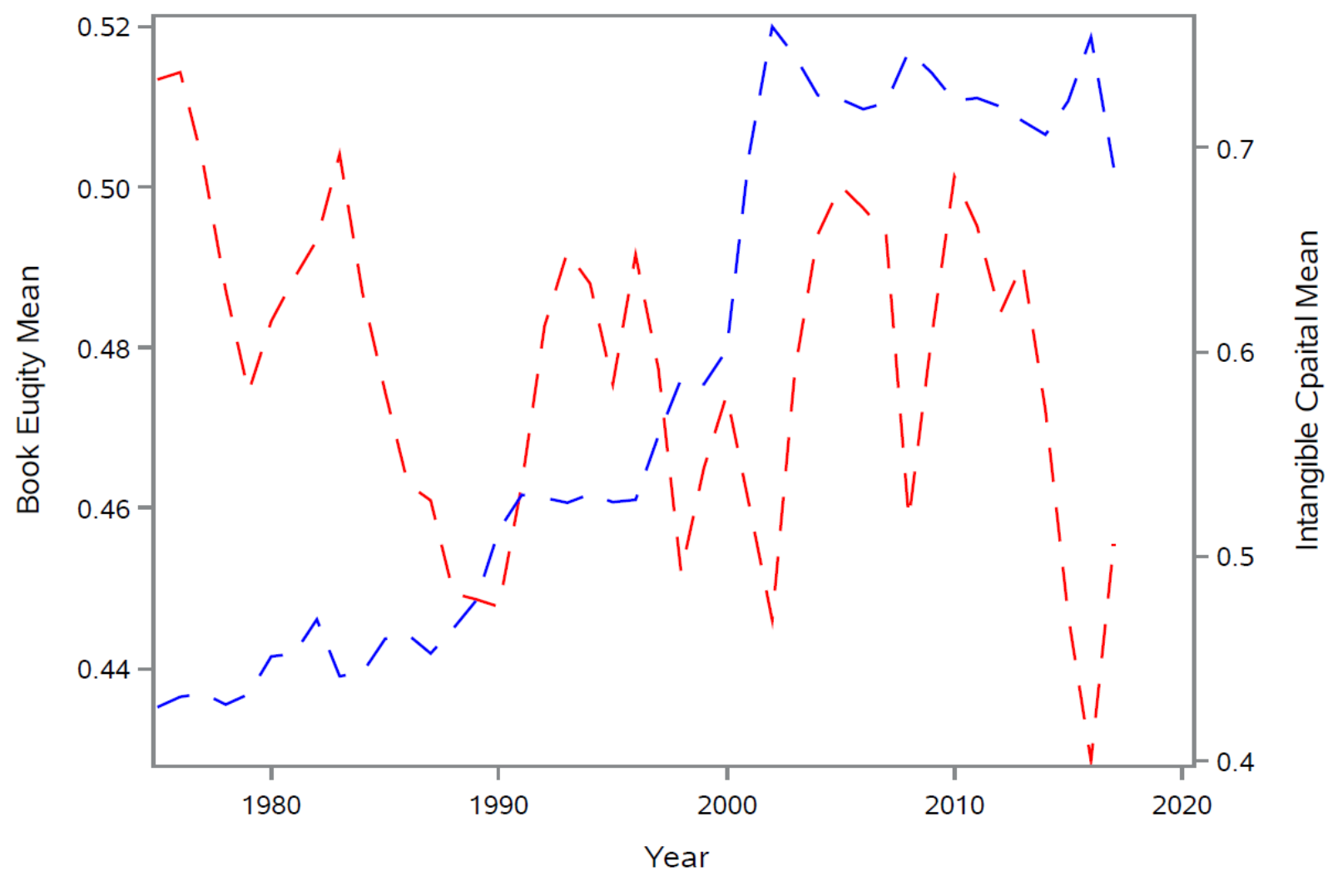

\subsection{OLS results and the cross-sectional relationship between intangible investments and book equity}

The results from the univariate analysis suggest that intangible investments may be an important explanatory variable for variation of book equity. In this section, we formally test this possibility as described in Hypothesis 1 using regression analysis. We start by examining the pooled cross-sectional regression as specified in equation (1).

Table 2 reports the regression results. In all regressions, the t-statistics are calculated based on robust standard errors clustered by the firm (Petersen, 2009). Model 1 is the regression on intangible capital only. As shown, the coefficient on the intangible capital stock is negative and significant at the $1 \%$ level, consistent with the correlation coefficient reported in Table 1. In Model (2), we added all control variables in the regression and examined the effect of intangible capital on B.E. To control for unobserved, time-invariant factors; we also control for firm fixed effects in this specification. The coefficient on intangible capital remains negative and statistically significant at the $1 \%$ level. Also, notice that the effect of intangible capital on book equity increased as the absolute value of coefficient increased significantly. The explanatory power of the model also improved as adjusted R-square increased from 0.0086 to 0.6327 . We re-estimated model (2) using lagged changes (first difference) regressions in models (3). In this new specification, the coefficient on intangible capital remains negative and statistically significant. 
Among other variables in all specifications, we find that the signs and magnitudes of independent variables are consistent with prior literature and our expectations. Specifically, firms' book equity ratios are generally positively associated with profitability, dividend dummy and capital expenditures. Book equity is negatively related to leverage, share repurchase, and tangibility. Note that both the negative coefficient of leverage and positive coefficient of profitability are significant at $1 \%$ level, providing the evidence that the negative effect of intangible capital on book equity is distinct from effects from leverage and profitability and remain significant even after we have controlled these effects.

\section{Table 2: Cross-sectional relationship between intangible capital and book equity}

This table provides regression results of book equity on intangible capital and other control variables over the sample period 1975-2017. All variables are winsorized at the 1\% level. Our sample consists of 129,444 firm-year observations, and we exclude financial (SIC codes 6000-6999), utility (SIC codes 4900-4999), firms classified as public service, international affairs, or non-operating establishments ( SIC codes greater than 9000) and nonUS firms (FIC = USA). Book equity is defined as the sum of shareholders' book equity and balance sheet deferred taxes and investment tax credit, subtracting the book value of preferred stock, standardized by the total asset. Profitability, defined as operating income before depreciation over book assets; firm size, defined as the natural log of a firm's total assets; share repurchase, defined as the ratio of share repurchases to total assets; industry sales volatility, calculated as the standard deviation of sales over total assets for 5 years' rolling window for each industry ( 3 digit SIC code); tangibility, defined as property, plant and equipment to book assets; leverage, calculated as total debt over total assets; capital expenditure, measured by capital expenditure divided by total asset, and dividend dummy, which takes the value of 1 if the firm pays a dividend in that year and 0 otherwise.

\begin{tabular}{|c|c|c|c|}
\hline Model & 1 & 3 & 4 \\
\hline Dependent Variable & $B E$ & $B E$ & Change_BE \\
\hline Intercept & $\begin{array}{c}0.5039^{* * *} \\
(0.0036)\end{array}$ & $\begin{array}{r}0.6683^{* * *} \\
(0.0156)\end{array}$ & $\begin{array}{r}-0.0105^{* * *} \\
(0.0005)\end{array}$ \\
\hline Intangible Capital & $\begin{array}{c}-0.0547^{* * *} \\
(0.0053)\end{array}$ & $\begin{array}{r}-0.1204^{* * *} \\
(0.0066)\end{array}$ & $\begin{array}{r}-0.1078^{* * *} \\
(0.0066)\end{array}$ \\
\hline Leverage & & $\begin{array}{r}-0.2078^{* * *} \\
(0.0052)\end{array}$ & $\begin{array}{r}-0.2098^{* * *} \\
(0.0048)\end{array}$ \\
\hline Repurchase & & $\begin{array}{r}-0.1576^{* * *} \\
(0.0254)\end{array}$ & $\begin{array}{r}-0.1370^{* * *} \\
(0.0155)\end{array}$ \\
\hline Size & & $\begin{array}{r}0.0038 \\
(0.0027)\end{array}$ & $\begin{array}{r}0.0312^{* * *} \\
(0.0040)\end{array}$ \\
\hline Dividend & & $\begin{array}{r}0.0454^{* * *} \\
(0.0039)\end{array}$ & $\begin{array}{r}0.0114^{* * *} \\
(0.0019)\end{array}$ \\
\hline Industrial Sales Volatility & & $\begin{array}{r}0.0162 \\
(0.0251)\end{array}$ & $\begin{array}{r}0.0164 \\
(0.0145)\end{array}$ \\
\hline Tangibility & & $\begin{array}{r}-0.1039 * * * \\
(0.0155)\end{array}$ & $\begin{array}{r}-0.1309^{* * *} \\
(0.0149)\end{array}$ \\
\hline Profit & & $\begin{array}{r}0.2948^{* * *} \\
(0.0129)\end{array}$ & $\begin{array}{r}0.2781^{* * *} \\
(0.0085)\end{array}$ \\
\hline Capital Expenditure & & $\begin{array}{r}0.0914^{* * *} \\
(0.0178)\end{array}$ & $\begin{array}{l}0.0387^{* *} \\
(0.0122)\end{array}$ \\
\hline Firm F.E. & No & Yes & No \\
\hline Industry F.E. & Yes & No & Yes \\
\hline Year F.E. & Yes & Yes & Yes \\
\hline Adjusted $R^{2}$ & 0.0086 & 0.6327 & 0.1799 \\
\hline
\end{tabular}




\subsection{The evolving effect of intangible investments and book equity over time}

In this section, we turn our focus to analyze how the effect of intangible capital on book equity evolving over time. As we discussed in previous sections, in an increasingly knowledge-based economy, many industries are transforming from tangible-based to intangible-intensive ones. As we plotted in Figure 4, the intangible capital investments for average firms are consistently increasing over our sample period. Some recent literature (e.g. He and Wintoki 2016) also document that R\&D intensity increased across all industries between 1980 and 2012. One implication emerges from these findings: the effect of intangible capital on book equity deepens over time, and there is a fundamental shift in the association between intangible capital and book equity that could explain a considerable portion of the decrease in book equity in recent years. This conjecture thus leads us to make the following hypothesis:

Hypothesis 2: Intangible capital investment has become an increasingly important determinant of book equity in recent years.

To test this hypothesis, we estimate equation (1) for successive five-year periods between 1975 and 2015 and compare the changing effect of intangible capital on book equity while controlling other firm characteristics that might also have an increasing impact on book equity. The results are reported in Table 3.

As shown in the table, the effect of intangible capital has increased dramatically during our sample period. Across all regressions, the estimated coefficients are consistently negative and significant at $1 \%$ level. The absolute values of the estimated coefficient on intangible capital increased from 0.0326 in the 1975-1980 period to 0.1158 in the 2001-2005 period, then dropped slightly to 0.099 in the $2011-2015$ period. But even with the slight drop in most recent subperiod, the magnitude of the effect of intangible capital on book equity has increased 204\% between 1975 and 2015. In contrast, although the coefficients on leverage are consistently negative and statistically significant over time, the magnitude of effect has decreased. The absolute values of the estimated coefficient on leverage decreased from 0.4326 in 1975-1980 to 0.3573 in the $2011-2015$ period, a 17\% decrease. Similarly, for profitability, although estimated coefficients are consistently positive and significant, the magnitude of effect has decreased by $46 \%$ from 0.579 in the 1975-1980 period to 0.3146 in the $2011-2015$ period. Among all other variables, industry sales volatility and tangibility exhibit similar patterns as intangible capital, with an increasingly negative effect on book equity, but the magnitude is much smaller.

\section{Table 3: The evolving effects of intangible capital on book equity}

This table provides regression results of book equity on intangible capital and other control variables for successive five-year periods between 1975 and 2015. All variables are winsorized at the $1 \%$ level. Our sample consists of 129,444 firm-year observations, and we exclude financial (SIC codes 6000-6999), utility (SIC codes 4900-4999), firms classified as public service, international affairs, or non-operating establishments ( SIC codes greater than 9000) and non-US firms (FIC = USA). Book equity is defined as the sum of shareholders' book equity and balance sheet deferred taxes and investment tax credit, subtracting the book value of preferred stock, standardized by the total asset. profitability, defined as operating income before depreciation over book assets; firm size, defined as the natural log of a firm's total assets; share repurchase, defined as the ratio of share repurchases to total assets; industry sales volatility, calculated as the standard deviation of sales over total assets for 5 years' rolling window for each industry (3 digit SIC code); tangibility, defined as property, plant and equipment to book assets; leverage, calculated as total debt over total assets; capital expenditure, measured by capital expenditure divided by total asset, and dividend dummy, which takes the value of 1 if the firm pays a dividend in that year and 0 otherwise. ${ }^{*}, * *$, and ${ }^{* * *}$ indicate statistical significance at the $10 \%$, $5 \%$, and $1 \%$ level, respectively 


\begin{tabular}{|c|c|c|c|c|c|c|c|c|}
\hline & 1 & 2 & 3 & 4 & 5 & 6 & 7 & 8 \\
\hline 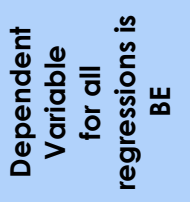 & $\begin{array}{l}\stackrel{0}{\alpha} \\
\frac{1}{n} \\
\stackrel{n}{-}\end{array}$ & $\begin{array}{l}\frac{2}{2} \\
\frac{1}{1} \\
2 \\
\frac{1}{-}\end{array}$ & 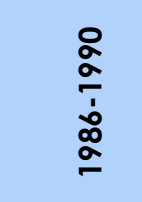 & $\frac{\stackrel{n}{\alpha}}{\frac{1}{\alpha}}$ & 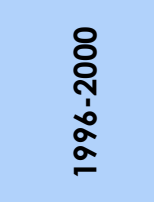 & 옹 & $\begin{array}{l}\text { 유 } \\
\text { ণ́ } \\
\text { 유 }\end{array}$ & 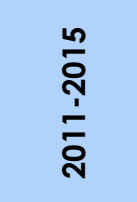 \\
\hline $\begin{array}{l}\frac{\hbar}{0} \\
\frac{0}{0} \\
\frac{0}{0} \\
\underline{\underline{\Xi}}\end{array}$ & $\begin{array}{l}0.7467^{* * *} \\
(0.0082)\end{array}$ & $\begin{array}{l}0.8261^{* * *} \\
(0.0091)\end{array}$ & $\begin{array}{l}0.8608^{* * *} \\
(0.0086)\end{array}$ & $\begin{array}{l}0.8496^{* * *} \\
(0.0087)\end{array}$ & $\begin{array}{l}0.9132 * * * \\
(0.0109)\end{array}$ & $\begin{array}{l}0.8867^{* * *} \\
(0.0110)\end{array}$ & $\begin{array}{l}0.8706^{* * *} \\
(0.0121)\end{array}$ & $\begin{array}{l}0.8869^{* * *} \\
(0.0268)\end{array}$ \\
\hline 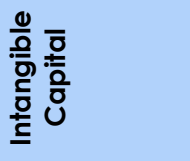 & $\begin{array}{c}-0.0326^{* * *} \\
(0.0047)\end{array}$ & $\begin{array}{c}-0.0484^{* * *} \\
(0.0057)\end{array}$ & $\begin{array}{c}-0.0690^{* * *} \\
(0.0049)\end{array}$ & $\begin{array}{c}-0.0702^{* * *} \\
(0.0047)\end{array}$ & $\begin{array}{l}-0.1196^{* * *} \\
(0.0051)\end{array}$ & $\begin{array}{c}-0.1158^{* * *} \\
(0.0052)\end{array}$ & $\begin{array}{c}-0.0883^{* * *} \\
(0.0053)\end{array}$ & $\begin{array}{c}-0.0990^{* * *} \\
(0.0121)\end{array}$ \\
\hline $\begin{array}{l}\frac{0}{0} \\
\frac{0}{\Phi} \\
\stackrel{\Xi}{త}\end{array}$ & $\begin{array}{c}-0.4326^{* * *} \\
(0.0072)\end{array}$ & $\begin{array}{c}-0.4583^{* * *} \\
(0.0078)\end{array}$ & $\begin{array}{c}-0.3785^{* * *} \\
(0.0067)\end{array}$ & $\begin{array}{c}-0.3769^{* * *} \\
(0.0062)\end{array}$ & $\begin{array}{c}-0.3592^{* * *} \\
(0.0069)\end{array}$ & $\begin{array}{c}-0.3203^{* * *} \\
(0.0066)\end{array}$ & $\begin{array}{c}-0.3229 * * * \\
(0.0070)\end{array}$ & $\begin{array}{c}-0.3573^{* * *} \\
(0.0162)\end{array}$ \\
\hline$\frac{\emptyset}{\stackrel{\Delta}{0}}$ & $\begin{array}{l}-0.0366 \\
(0.0713)\end{array}$ & $\begin{array}{l}-0.1265 \\
(0.0666)\end{array}$ & $\begin{array}{l}0.2417^{* *} \\
(0.0783)\end{array}$ & $\begin{array}{l}-0.1803^{* *} \\
(0.0570)\end{array}$ & $\begin{array}{c}0.0572 \\
(0.0688)\end{array}$ & $\begin{array}{l}-0.0374 \\
(0.0537)\end{array}$ & $\begin{array}{c}-0.3458^{* * *} \\
(0.0618)\end{array}$ & $\begin{array}{c}-0.5821^{* * *} \\
(0.1216)\end{array}$ \\
\hline$\stackrel{N}{N}$ & $\begin{array}{c}0.0055^{* * *} \\
(0.0012)\end{array}$ & $\begin{array}{c}-0.0064^{* * *} \\
(0.0014)\end{array}$ & $\begin{array}{c}-0.0157^{* * *} \\
(0.0013)\end{array}$ & $\begin{array}{c}-0.0093^{* * *} \\
(0.0013)\end{array}$ & $\begin{array}{c}-0.0046^{* *} \\
(0.0015)\end{array}$ & $\begin{array}{c}-0.0057^{* * *} \\
(0.0015)\end{array}$ & $\begin{array}{c}-0.0073^{* * *} \\
(0.0016)\end{array}$ & $\begin{array}{l}-0.0081^{*} \\
(0.0034)\end{array}$ \\
\hline $\begin{array}{l}\frac{0}{c} \\
\frac{0}{0} \\
\frac{0}{2} \\
\stackrel{0}{0}\end{array}$ & $\begin{array}{l}0.0990^{* * *} \\
(0.0041)\end{array}$ & $\begin{array}{l}0.1138^{* * *} \\
(0.0049)\end{array}$ & $\begin{array}{l}0.1015^{* * *} \\
(0.0048)\end{array}$ & $\begin{array}{l}0.0624^{* * *} \\
(0.0049)\end{array}$ & $\begin{array}{l}0.0589^{* * *} \\
(0.0060)\end{array}$ & $\begin{array}{l}0.0235^{* * *} \\
(0.0056)\end{array}$ & $\begin{array}{l}0.0390^{* * *} \\
(0.0056)\end{array}$ & $\begin{array}{l}0.0324^{* *} \\
(0.0121)\end{array}$ \\
\hline 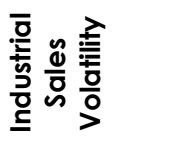 & $\begin{array}{l}0.0165 \\
(0.0377)\end{array}$ & $\begin{array}{c}-0.2619^{* * *} \\
(0.0419)\end{array}$ & $\begin{array}{c}-0.2711^{* * *} \\
(0.0511)\end{array}$ & $\begin{array}{c}-0.3946^{* * *} \\
(0.0532)\end{array}$ & $\begin{array}{c}-0.5154^{* * *} \\
(0.0489)\end{array}$ & $\begin{array}{c}-0.4056^{* * *} \\
(0.0527)\end{array}$ & $\begin{array}{c}-0.3736^{* * *} \\
(0.0528)\end{array}$ & $\begin{array}{c}-0.3327^{* *} \\
(0.1190)\end{array}$ \\
\hline 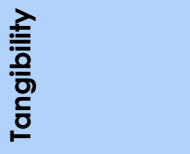 & $\begin{array}{c}-0.1035^{* * *} \\
(0.0104)\end{array}$ & $\begin{array}{c}-0.0614^{* * *} \\
(0.0112)\end{array}$ & $\begin{array}{c}-0.1426^{* * *} \\
(0.0109)\end{array}$ & $\begin{array}{c}-0.1443^{* * *} \\
(0.0111)\end{array}$ & $\begin{array}{c}-0.2784^{* * *} \\
(0.0135)\end{array}$ & $\begin{array}{c}-0.2164^{* * *} \\
(0.0142)\end{array}$ & $\begin{array}{c}-0.1664^{* * *} \\
(0.0144)\end{array}$ & $\begin{array}{c}-0.1379^{* * *} \\
(0.0311)\end{array}$ \\
\hline 壳 & $0.5790^{* * *}$ & $0.4983^{* * *}$ & $0.2827^{* * *}$ & $0.3362^{* * *}$ & $0.2823^{* * *}$ & $0.2372^{* * *}$ & $0.2435^{* * *}$ & $0.3146^{* * *}$ \\
\hline 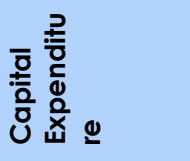 & $\begin{array}{l}0.0771^{* *} \\
(0.0238)\end{array}$ & $\begin{array}{l}0.0610 * \\
(0.0298)\end{array}$ & $\begin{array}{l}0.3246^{* * *} \\
(0.0314)\end{array}$ & $\begin{array}{l}0.1633^{* * *} \\
(0.0314)\end{array}$ & $\begin{array}{l}0.3165^{* * *} \\
(0.0453)\end{array}$ & $\begin{array}{l}0.1352^{* *} \\
(0.0436)\end{array}$ & $\begin{array}{c}0.0237 \\
(0.0475)\end{array}$ & $\begin{array}{l}0.0323 \\
(0.1137)\end{array}$ \\
\hline Industry F.E. & Yes & Yes & Yes & Yes & Yes & Yes & Yes & Yes \\
\hline Year F.E. & Yes & Yes & Yes & Yes & Yes & Yes & Yes & Yes \\
\hline Adjusted R2 & 0.3303 & 0.2947 & 0.2615 & 0.2456 & 0.2440 & 0.2367 & 0.2245 & 0.2283 \\
\hline
\end{tabular}




\section{How Much of the Change in Book Equity Can be Attributed to Intangible Capital?}

The results from Table 3 suggest that the effect of intangible capital on book equity has increased over recent decades. However, we also observe that other firm characteristics, such as profitability and leverage, exhibit time-varying effects on book equity during the sample period. In this section, we turn our analysis to identify and quantify the main driving forces of decreasing book equity among various firm characteristics. Specifically, we investigate how firm characteristics change and how the sensitivity of book equity to firm characteristics change, respectively, affect book equity levels over time.

We start with the first possible source for the aggregate decrease in book equity: changing firm characteristics. To isolate the effect of changing firm characteristics, we must hold the sensitivity of independent variables constant and only use time-varying firm characteristics to calculate changes in book equity. Since we are holding sensitivity constant, the resulting changes in book equity are solely due to changing firm characteristics. In an effort to track the evolution of such effect, we perform separate calculations on each of the three most recent decades ((i.e., the 1990s, 2000s and 2010s). Specifically, for each of three decades, we estimate regression models as in Model 2 of Table 2 for a sample consist of firms during the previous 10 years, which we call the base period. For example, to evaluate how changing firm characteristics affect book equity during the 1990s, we estimate model 2 using sample firms during the base period (1980-1989) and record the estimated coefficients, assuming the estimated coefficients during the base period persist during 1990s. We then calculate the change in the mean value for each firm characteristics variable between the base period (19801989) and 1990s. Lastly, we multiply calculated change by the estimated coefficient from the base period for each firm characteristics to obtain the change in book equity due to each firm characteristics variable for the 1990s. To make sure that we use the most recent information when estimating coefficients, we use a rolling base period for each decade. For example, the base period for the 2000s is the ten-year-period between 1990 and 1999, and the base period for 2010s is the ten-year-period between 2000 and 2009. Table 4 reports the main results of our analysis.

Panel A of Table 4 report changes of mean firm characteristics for each decade. It appears that intangible capital, on average, is consistently increasing over each decade, with the incremental amount maximized during the 2000s. Similarly, repurchase and size are also consistently increasing each decade. In contrast, tangibility and capital expenditure are steadily decreasing over time. Panel B of Table 4 presents the results of the effect of changing firm characteristics on book equity for each decade. Holding sensitivity constant, increasing intangible capital alone result in book equity ratio to decrease by $0.8 \%, 1.44 \%$ and $0.4 \%$ for each decade. Beside intangible capital, changes in repurchase and capital expenditure also contribute to a decrease in book equity, but the magnitude is much smaller relative to that of intangible capital. In contrast, the effect of leverage and probability are time-sensitive. For leverage, its variation contributes to a decrease in book equity only during the 2010 s. For profitability, its variation contributes to a decrease in book equity during the 1990s and 2000s but not 2010s. 


\section{Table 5: Decrease in book equity and changing sensitivity of book equity on firm characteristics}

This table presents the decomposed effect of changing sensitivity of book equity on firm characteristics for each of the three most recent decades ((i.e., 1990s, 2000s and 2010s). For each decade, we first calculate the mean value for each firm characteristic variable and assume these values persist into each decade. We then estimate Equation 1 for each decade and its corresponding base period, respectively, and calculate the change in coefficient for each independent variable. Lastly, we multiply calculated change of sensitivity by mean value for each firm characteristic variable from base period to obtain the change in book equity due to changing sensitivity of individual firm characteristics. We use rolling base period for each decade. For example, the base period for 2000s is the ten-year-period between 1990 and 1999, and the base period for 2010s is the ten-year-period between 2000 and 2009.

\section{Panel A}

Change of sensitivity of Firm Characteristics from Corresponding Base Period

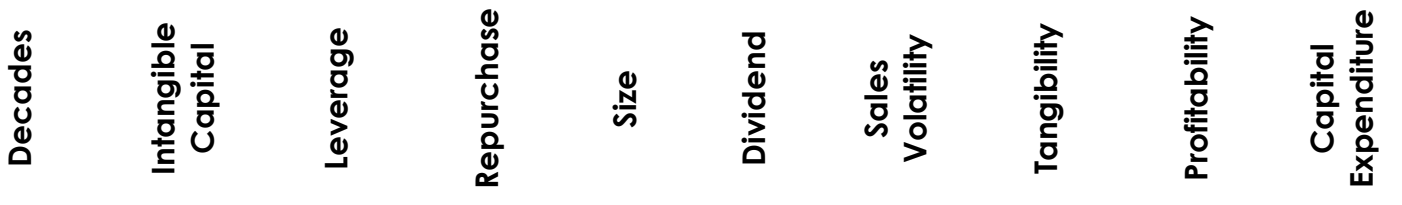

\begin{tabular}{llllllllll}
\hline 1990s & $-0.43 \%$ & $-18.80 \%$ & $5.83 \%$ & -0.012 & $4.14 \%$ & $-31.15 \%$ & $-5.16 \%$ & $-4.34 \%$ & $17.45 \%$ \\
2000s & $-3.19 \%$ & $-13.83 \%$ & $10.92 \%$ & -0.001 & $-1.08 \%$ & $-47.31 \%$ & $-18.47 \%$ & $-10.99 \%$ & $19.77 \%$ \\
2010s & $3.08 \%$ & $-13.19 \%$ & $-30.57 \%$ & -0.006 & $-0.39 \%$ & $-39.85 \%$ & $-5.10 \%$ & $-5.21 \%$ & $-7.05 \%$ \\
\hline
\end{tabular}

\section{Panel B}

Effect of Changing sensitivity of Firm Characteristics on Book Equity

\begin{tabular}{|c|c|c|c|c|c|c|c|}
\hline $\begin{array}{l}\frac{0}{0} \overline{0} \\
\text { 음 } \\
\text { 동 } \\
\text { 음 }\end{array}$ & 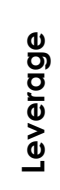 & 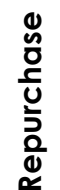 & $\stackrel{n}{n}$ & $\begin{array}{l}\frac{7}{c} \\
\frac{0}{0} \\
\frac{0}{2} \\
\frac{0}{0}\end{array}$ & 造 & 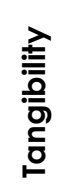 & 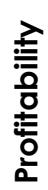 \\
\hline
\end{tabular}

\begin{tabular}{cccccccccc}
\hline $1990 \mathrm{~s}$ & $-0.18 \%$ & $-15.85 \%$ & $0.04 \%$ & -0.050 & $2.47 \%$ & $-2.17 \%$ & $-1.86 \%$ & $-0.61 \%$ & $1.51 \%$ \\
$\mathbf{2 0 0 0 \mathrm { s }}$ & $-1.67 \%$ & $-11.12 \%$ & $0.11 \%$ & -0.007 & $-0.35 \%$ & $-2.32 \%$ & $-6.05 \%$ & $-1.06 \%$ & $1.52 \%$ \\
$\mathbf{2 0 1 0 \mathrm { s }}$ & $2.07 \%$ & $-10.06 \%$ & $-0.55 \%$ & -0.036 & $-0.10 \%$ & $-2.38 \%$ & $-1.39 \%$ & $-0.30 \%$ & $-0.41 \%$ \\
Average & $0.08 \%$ & $-12.34 \%$ & $-0.13 \%$ & -0.031 & $0.67 \%$ & $-2.29 \%$ & $-3.10 \%$ & $-0.66 \%$ & $0.87 \%$ \\
\hline
\end{tabular}

Table 5 reports the results. In panel A of Table 5, we find that estimated coefficient, although consistently negative during each decade and its corresponding base period 6 , become less negative in the 2010s. As a result, the changes of sensitivity remain negative during the 1990s and 2000s but become positive $3.08 \%$ during 2010 s (the coefficient on intangible capital become less negative from 2000s to 2010s). In contrast, sensitivities of leverage, size, industry sales volatility, tangibility and profitability consistently become more negative each decade. Panel B of Table 5 presents the

6 In untabulated results, the estimated coefficients on intangible capital are consistently negative for 1990s, 2000s and 2010s 
results on the effect of changing sensitivity on book equity while holding firm characteristics constant. Unlike the effect of changing firm characteristics, we observe that changing sensitivity of intangible capital leads to a decrease in book equity ratio by $0.18 \%$ and $1.67 \%$ during the 1990 s and 2000 s but causes book equity to increase by $2.07 \%$ during $2010 \mathrm{~s}$. In contrast, changing sensitivities of leverage, size, industry sales volatility, tangibility and profitability are the main driving forces to bring down the book equity during each of three decades.

\section{Robustness}

One concern about our main findings on the relationship between intangible capital and book equity is that our sample covers firm-year observations over 40 years and sample composition could systematically shift over time. To address this issue, we form a subsample of firms that survived the entire period between 1975 and 2015 and reestimate equation 1 for the subsample as well as successive five-year periods between 1975 and 2015 as reported in Table 2 and Table 3. The results are presented in Table 6 below.

Column 1 of Table 6 shows the estimated coefficients of regression using full sample period for surviving firms. Similar to model 2 in Table 2, we control for unobserved, timeinvariant factors by adding firm fixed effects in this specification. As shown, the coefficient on intangible capital remains negative and statistically significant at the $1 \%$ level for such a restricted sample of survivors. Column 2 to column 9 report regression results for subsamples for each five-year period between 1975 and 2015. Similar to those reported in Table 3, the coefficients on intangible capital are consistently negative and significant at 1\% level in all subsamples except for the 1975-1980 period and 2006-2010. The absolute values of the estimated coefficient on intangible capital increased from 0.0055 in the 1975-1980 period to 0.0735 in the 2011 - 2015 period, suggesting the magnitude of the effect of intangible capital on book equity has increased $120 \%$ between 1975 and 2015. The increase is slightly lower than that reported using the full sample but still impressive and economically significant. Overall, our main results remain valid in the more restricted sample of survivors.

\section{Table 6: Robustness check using restricted survivor sample}

This table presents the regression results of the cross-sectional relationship between intangible capital and book equity as in equation 1 for the subsample of firms that survived the entire period between 1975 and 2015 as well as successive five-year periods between 1975 and 2015 as reported in Table 2 and Table 3 . we exclude financial (SIC codes 6000-6999), utility (SIC codes 4900-4999), firms classified as public service, international affairs, or non-operating establishments (SIC codes greater than 9000) and non-US firms (FIC = USA). Book equity is defined as the sum of shareholders' book equity and balance sheet deferred taxes and investment tax credit, subtracting the book value of preferred stock, standardized by the total asset. profitability, defined as operating income before depreciation over book assets; firm size, defined as the natural log of a firm's total assets; share repurchase, defined as the ratio of share repurchases to total assets; industry sales volatility, calculated as the standard deviation of sales over total assets for 5 years' rolling window for each industry ( 3 digit SIC code); tangibility, defined as property, plant and equipment to book assets; leverage, calculated as total debt over total assets; capital expenditure, measured by capital expenditure divided by total asset, and dividend dummy, which takes the value of 1 if the firm pays a dividend in that year and 0 otherwise. *, **, and ${ }^{* * *}$ indicate statistical significance at the $10 \%, 5 \%$, and $1 \%$ level, respectively 


\begin{tabular}{|c|c|c|c|c|c|c|c|c|c|}
\hline & 1 & 2 & 3 & 4 & 5 & 6 & 7 & 8 & 9 \\
\hline 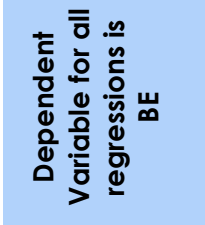 & 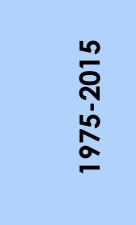 & $\frac{\stackrel{8}{\circ}}{\frac{5}{2}}$ & $\frac{\stackrel{2}{\circ}}{\frac{1}{\infty}}$ & $\begin{array}{l}\stackrel{\circ}{\circ} \\
\frac{1}{\circ} \\
\stackrel{\circ}{0}\end{array}$ & $\frac{\frac{2}{\alpha}}{\frac{1}{\alpha}}$ & 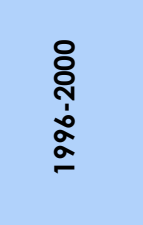 & 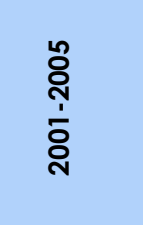 & 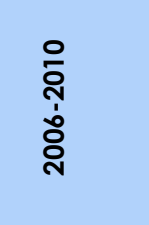 & $\frac{n}{\frac{n}{2}}$ \\
\hline Intercept & $\begin{array}{l}0.4956 * * \\
(0.0576)\end{array}$ & $\begin{array}{l}0.5999^{* * *} \\
(0.0183)\end{array}$ & $\begin{array}{l}0.6208^{* * *} \\
(0.0237)\end{array}$ & $\begin{array}{c}0.7273^{* * *} \\
(0.0259)\end{array}$ & $\begin{array}{l}0.8199^{* * *} \\
(0.0220)\end{array}$ & $\begin{array}{c}0.8207^{* * *} \\
(0.0220)\end{array}$ & $\begin{array}{l}0.8465^{* * *} \\
(0.0255)\end{array}$ & $\begin{array}{c}0.8487^{* * *} \\
(0.0236)\end{array}$ & $\begin{array}{c}0.8733^{* * *} \\
(0.0269)\end{array}$ \\
\hline $\begin{array}{l}\text { Intangible } \\
\text { Capital }\end{array}$ & $\begin{array}{c}-0.0918^{* * *} \\
(0.0246)\end{array}$ & $\begin{array}{l}-0.0055 \\
(0.0114)\end{array}$ & $\begin{array}{l}-0.0314^{* *} \\
(0.0117)\end{array}$ & $\begin{array}{l}-0.0316^{*} \\
(0.0153)\end{array}$ & $\begin{array}{c}-0.0643^{* * *} \\
(0.0123)\end{array}$ & $\begin{array}{c}-0.0716^{* * *} \\
(0.0128)\end{array}$ & $\begin{array}{l}-0.0312^{*} \\
(0.0153)\end{array}$ & $\begin{array}{l}-0.0281 \\
(0.0147)\end{array}$ & $\begin{array}{c}-0.0735^{* * *} \\
(0.0151)\end{array}$ \\
\hline everage & $\begin{array}{c}-0.2261^{* * *} \\
(0.0151)\end{array}$ & $\begin{array}{c}-0.2857^{* * *} \\
(0.0135)\end{array}$ & $\begin{array}{c}-0.2888^{* * *} \\
(0.0180)\end{array}$ & $\begin{array}{c}-0.2951^{* * *} \\
(0.0212)\end{array}$ & $\begin{array}{c}-0.2724^{* * *} \\
(0.0174)\end{array}$ & $\begin{array}{c}-0.3183^{* * *} \\
(0.0176)\end{array}$ & $\begin{array}{c}-0.2672^{* * *} \\
(0.0209)\end{array}$ & $\begin{array}{c}-0.2467^{* * *} \\
(0.0171)\end{array}$ & $\begin{array}{c}-0.2557^{* * *} \\
(0.0195)\end{array}$ \\
\hline epurchase & $\begin{array}{c}-0.3468^{* * *} \\
(0.0700)\end{array}$ & $\begin{array}{l}0.0804 \\
(0.1909)\end{array}$ & $\begin{array}{l}-0.2824 \\
(0.1523)\end{array}$ & $\begin{array}{l}-0.0659 \\
(0.1367)\end{array}$ & $\begin{array}{l}0.0080 \\
(0.1469)\end{array}$ & $\begin{array}{l}-0.3333^{* *} \\
(0.1079)\end{array}$ & $\begin{array}{l}-0.0704 \\
(0.1544)\end{array}$ & $\begin{array}{l}-0.1174 \\
(0.1104)\end{array}$ & $\begin{array}{l}-0.2614 \\
(0.1351)\end{array}$ \\
\hline Size & $\begin{array}{l}0.0151^{*} \\
(0.0073)\end{array}$ & $\begin{array}{l}0.0009 \\
(0.0019)\end{array}$ & $\begin{array}{l}-0.0059 * \\
(0.0024)\end{array}$ & $\begin{array}{c}-0.0247^{* * *} \\
(0.0028)\end{array}$ & $\begin{array}{c}-0.0388^{* * *} \\
(0.0024)\end{array}$ & $\begin{array}{c}-0.0291^{* * *} \\
(0.0023)\end{array}$ & $\begin{array}{c}-0.0357^{* * *} \\
(0.0028)\end{array}$ & $\begin{array}{c}-0.0336^{* * *} \\
(0.0027)\end{array}$ & $\begin{array}{c}-0.0345^{* * *} \\
(0.0030)\end{array}$ \\
\hline Dividend & $\begin{array}{c}0.0643^{* * *} \\
(0.0128)\end{array}$ & $\begin{array}{l}0.0810^{* * *} \\
(0.0089)\end{array}$ & $\begin{array}{l}0.1095^{* * *} \\
(0.0115)\end{array}$ & $\begin{array}{l}0.1470^{* * *} \\
(0.0131)\end{array}$ & $\begin{array}{l}0.1156^{* * *} \\
(0.0107)\end{array}$ & $\begin{array}{c}0.0673^{* * *} \\
(0.0097)\end{array}$ & $\begin{array}{l}0.1186^{* * *} \\
(0.0108)\end{array}$ & $\begin{array}{c}0.1255^{* * *} \\
(0.0106)\end{array}$ & $\begin{array}{l}0.1475^{* * *} \\
(0.0115)\end{array}$ \\
\hline $\begin{array}{l}\text { Industrial Sales } \\
\text { Volatility }\end{array}$ & $\begin{array}{l}0.0020 \\
(0.0595)\end{array}$ & $\begin{array}{l}-0.0493 \\
(0.0759)\end{array}$ & $\begin{array}{l}0.2087^{*} \\
(0.0871)\end{array}$ & $\begin{array}{c}-0.3387^{* * *} \\
(0.0948)\end{array}$ & $\begin{array}{l}-0.2168 \\
(0.1173)\end{array}$ & $\begin{array}{l}-0.1578 \\
(0.1059)\end{array}$ & $\begin{array}{l}-0.1957^{*} \\
(0.0968)\end{array}$ & $\begin{array}{c}-0.3131^{* * *} \\
(0.0889)\end{array}$ & $\begin{array}{c}-0.3632^{* * *} \\
(0.0912)\end{array}$ \\
\hline angibility & $\begin{array}{l}0.1118^{* *} \\
(0.0406)\end{array}$ & $\begin{array}{c}0.0763^{* * *} \\
(0.0229)\end{array}$ & $\begin{array}{l}0.0606^{*} \\
(0.0272)\end{array}$ & $\begin{array}{c}0.0256 \\
(0.0332)\end{array}$ & $\begin{array}{c}0.0516 \\
(0.0286)\end{array}$ & $\begin{array}{c}0.0381 \\
(0.0271)\end{array}$ & $\begin{array}{c}0.0055 \\
(0.0322)\end{array}$ & $\begin{array}{l}0.0641^{*} \\
(0.0301)\end{array}$ & $\begin{array}{l}0.0648^{*} \\
(0.0322)\end{array}$ \\
\hline Profit & $\begin{array}{c}0.3777^{* * *} \\
(0.0490)\end{array}$ & $\begin{array}{c}0.7078^{* * *} \\
(0.0386)\end{array}$ & $\begin{array}{c}0.6983^{* * *} \\
(0.0455)\end{array}$ & $\begin{array}{c}0.5575^{* * *} \\
(0.0597)\end{array}$ & $\begin{array}{c}0.6010^{* * *} \\
(0.0588)\end{array}$ & $\begin{array}{c}0.7067^{* * *} \\
(0.0594)\end{array}$ & $\begin{array}{c}0.3057^{* * *} \\
(0.0734)\end{array}$ & $\begin{array}{l}0.1232 \\
(0.0664)\end{array}$ & $\begin{array}{c}0.2596^{* * *} \\
(0.0768)\end{array}$ \\
\hline $\begin{array}{l}\text { Capital } \\
\text { Expenditure }\end{array}$ & $\begin{array}{c}0.0198 \\
(0.0633)\end{array}$ & $\begin{array}{c}-0.4347^{* * *} \\
(0.0646)\end{array}$ & $\begin{array}{l}-0.1036 \\
(0.0825)\end{array}$ & $\begin{array}{l}0.2493^{*} \\
(0.1226)\end{array}$ & $\begin{array}{l}0.0156 \\
(0.1065)\end{array}$ & $\begin{array}{l}0.1246 \\
(0.0956)\end{array}$ & $\begin{array}{l}0.4017^{* *} \\
(0.1362)\end{array}$ & $\begin{array}{c}0.1461 \\
(0.1337)\end{array}$ & $\begin{array}{l}-0.2854 \\
(0.1459)\end{array}$ \\
\hline Firm F.E. & Yes & No & No & No & No & No & No & No & No \\
\hline Industry F.E. & No & Yes & Yes & Yes & Yes & Yes & Tes & Yes & Yes \\
\hline Year F.E. & Yes & Yes & Yes & Yes & Yes & Yes & Yes & Yes & Yes \\
\hline Adjusted $R^{2}$ & 0.5539 & 0.3867 & 0.2995 & 0.2628 & 0.3494 & 0.3285 & 0.2663 & 0.2816 & 0.2635 \\
\hline
\end{tabular}

\section{Conclusion}

We document that the book equity of U.S. firms has decreased dramatically over time. Such a systematic decrease may reflect overall companies' attitudes on intangible assets. We find that intangible capital investments play an essential role in explaining decreasing book equity. The negative relationship between intangible capital and book equity is persistent across many model specifications. We also find that the negative effect is more pronounced in recent years. To understand how intangible capital affects book equity and compare it with other explanatory variables, we isolate the effect of changing firm characteristics from the effect of changing the sensitivity of firm characteristics on book equity. Our analysis shows that intangible capital 
contributes to a decrease in book equity mostly through the channel of changing firm characteristics. The changing sensitivity of intangible capital explains the decrease in book equity during the 1990s and 2000s but not 2010s. In contrast, changing sensitivities of leverage, size, industry sales volatility, tangibility and profitability are the main driving forces to bring down the book equity during the 2010s. Our findings call for a revision of accounting standards to clearly define the boundaries of intangible assets and reflect such assets in book value. Investors also must incorporate the effect of intangible capital into their valuation analysis, as indexes or investment strategies relying on indicators constructed by book equity may be biased and misleading.

\section{References}

Breusch, T.S. and Pagan, A.R., 1980. The Lagrange multiplier test and its applications to model specification in econometrics. The review of economic studies, 47(1), pp.239-253.

DeAngelo, H. and Roll, R., 2015. How stable are corporate capital structures? The Journal of Finance, 70(1), pp.373-418.

Darrough, M. and Ye, J., 2007. Valuation of loss firms in a knowledge-based economy. Review of Accounting Studies, 12(1), pp.61-93.

Fama, E.F. and French, K.R., 2008. Dissecting anomalies. The Journal of Finance, 63(4), pp.1653-1678.

Graham, J.R., Leary, M.T. and Roberts, M.R., 2015. A century of capital structure: The leveraging of corporate America" Journal of Financial Economics, 118(3), pp.658-683.

Hall, B.H., 1993. The stock market's valuation of R\&D investment during the 1980's. The American Economic Review, 83(2), pp.259-264.

He, Z. and Wintoki, M.B., 2016. The cost of innovation: R\&D and high cash holdings in U.S. firms. Journal of Corporate Finance, 41, pp.280-303.

Hausman, J.A., 1978. Specification tests in econometrics. Econometrica: Journal of the econometric society, pp.1251-1271.

Jan, C.L. and OU, J.A., 2011. Negative-book-value firms and their valuation. Accounting horizons, 26(1), pp.91-110.

Luo, H., Liu, I. and Tripathy, N., 2019. A Study on Firms with Negative Book Value of Equity. International Review of Finance.

Petersen, M.A., 2009. Estimating standard errors in finance panel data sets: Comparing approaches. The Review of Financial Studies, 22(1), pp.435-480.

Peters, R.H. and Taylor, L.A., 2017. "Intangible capital and the investment-q relation." Journal of Financial Economics, 123(2), pp.251-272. 